\title{
Family Counseling in Pandemic Era
}

\author{
Fatrida Anugrah Syafri; Badeni; Muhammad Kristiawan \\ Bengkulu University, Indonesia \\ http://dx.doi.org/10.18415/ijmmu.v9i2.3383
}

\begin{abstract}
The formulation of the problem aims to discover the roles parents take while accompanying their children during the Covid-19 pandemic. This study is done using thematic analysis through case study interviews on 6 mothers and 3 fathers. The results show that parents take the roles that emerge as mentors, educators, custodians, developers and supervisors. Parent's roles that emerge in particular includes: ensuring and maintaining children live clean and healthy, accompanying children in finishing schoolwork, doing activities together at home, provide education, establishing intense communication, creating a comfortable environment, playing together, be a role model for children, supervise the family, provide and fulfill family necessities, motivate, guide, maintain religion values, and carry out a variety of innovations in home activities. Parents require guidance to help accompany children's activities based on their children's needs during the pandemic.
\end{abstract}

Keywords: Role of Parents; Family Counseling; Pandemic Period

\section{Introduction}

On March 2, 2020, President Joko Widodo directly conveyed the spread of this virus that was first discovered in Indonesia, (Nuraini, 2020). It currently has infected 23,165 people resulting in 1,418 deaths, and 5,877 recovered patients. (covid19.go.id, 2020). The government has taken several approaches to stop the virus's dissemination chain, such as declaring PP No. 21 of 2020 regarding Large Scale Social Restrictions to Hasten Covid-19 Handling, which restricted a variety of activities, including schools and education. Meanwhile, The Minister of Education has taken steps to prevent the spreading of Corona Virus and has officially issued Learning From Home (BDR) activities through Circular Letter Culture Number 36962/MPK.A/HK/2020 addressing working from home and online learning (COVID19).

Of course, this policy will have an impact on not just the teacher-student connection while implementing BDR, but also the significance of parents' involvement in the process. Parents' role to accompany their children to be successful during home learning is very important, and in this aspect, 
WHO (2020) has published various guide for parents to support their children during the pandemic, including being more active and constructive during helping children Sexual parenting skills activities at home. Parents' roles in influencing basic abilities and attitudes, for instance theological education for obeying norms and creating good practices (Nurlaeni \& Juniarti, 2017), have grown to include becoming academic companions. Prabhawani (2016) pointed out that it is the parent's responsibility as well as the broader community, not just educational institutions, to implement education.

When it comes to the role of parents, it is inseparable from the family. Lestari, (2012) pointed out that family is perceived in terms of its functions, i.e. having functions and obligations of caring, emotional, providing economic support, and

Achievement of certain roles. The family, according to Muchtar (in Lutfatutatifah et al. 2015), is an essential part of the community unit. Families have a vital role in the care, education, protection, and upbringing of children. According to Candra et al. (2013), parental care for children can influence the development of children's personality and conduct. If parenting is wrong, the impact on children as adults.

According to Rakhmawati (2015), Child care is a continuous activity that promotes children's healthy growth and development by allowing parents and children to interact. As explained by Rosdiana (2006), the preceding explanation demonstrates that, thus far, parents' role in nurturing and caring for their children has grown in importance, although academic education is typically delegated to a third party, notably the school. In fact, the majority of parents assume that their obligations in educating their children have been met once their children have enrolled in a school. Before the pandemic, the following definition of the role of parents was studied more thoroughly, which concentrated more on care and care, while intellectual instruction was left to the school. Meanwhile, there hasn't been much study done on the function of parents during a pandemic. Based on the foregoing, the research in this study is critical in determining the true parents' role in accompanying their children during the Covid-19 epidemic, even when guiding children to study at home.

Rakhmawati (2015), states that childcare is a continuous activity that encourages optimal growth and development in children through an interactive process between parents and children. This explanation shows that parental role in upbringing and care has been more prominent so far, meanwhile formal education is likely assigned to a second party, or as stated by Rosdiana (2006), the school. In practice most parents still believe that they completed educating Children's obligations after entering the school institution. The role of parents' description above was analyzed more preceding the outbreak, and more emphasis was placed on caring and caring, whereas academic education was the responsibility of the school. Meanwhile, the role of parents' research during the pandemic has not been widely conducted. Taken together, the research in this study is important for understanding the true role of parents in accompanying their children to study from home.

\section{Research Methods}

Case study is the method used in this research design to reveal a more detailed and comprehensive picture of the subject being analysed (Alwasilah, 2002). Yin, (2003) stated that case studies are well suited to answer "how" questions, as these types of questions will explore the data in greater depth. In this context, the study analyzed the role of parents in accompanying their children during the Covid19 pandemic. The subjects of this study were parents of young children and primary school age, a total of 9 people ( 6 mothers, 3 fathers). The data collection techniques used were interviews and thematic analysis, i.e. analytical techniques that emphasized preparation of coding with reference to the identified research question in order to arrange the themes according to the research questions and 
become a reference in explaining the phenomena that occur. (Heriyanto, 2018). In more detail, the explanation of the research flow can be seen in Figure 1 below.

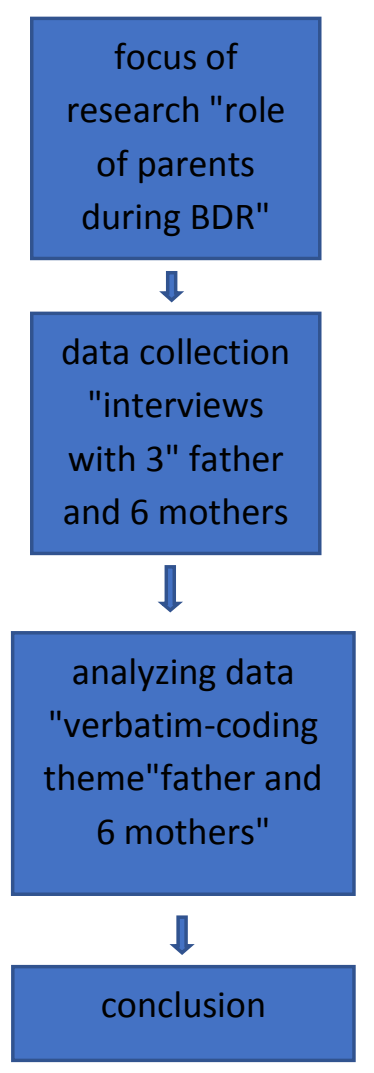

Figure 1. Research Flow

\section{Results}

The Covid-19 virus, which has spread to nearly every country on the planet, highlights the rising significance of the family's role in the nurturing, caring, and education of the children. This event revives the family's original role as the center of all activities and the primary location for children's education.

As explained by one parent below. ... Yes, to reestablish the family's primary function as the focus of all activities.... yes...to restore togetherness .. intimacy... (SP interview excerpt) Family will never be able to be separated from children's lives, as the first and main place in the beginning of their lives. Social values, morals, and religion can be taught more effectively in the family than in other institutions. As revealed by Zahrok \& Suarmini, (2018) that The family has a critical role in imparting behavioural patterns, as well as religion, ethics, and values that are appropriate for the family's culture and age. According to the Government Regulation of the Republic of Indonesia No. 21 of 1994 on the Implementation of Prosperous Family Development, 1994, the family serves the duties of love and affection, protection, education, values, religion, morals, and social. According to Alfiana (2013), the family is the primary or starting point and the nearest place for children because there is a lot of free time to spend with children in the family. Also stated by Zahrok \& Suarmini, (2018), that one of the most essential influences in making children thrive is the home as the primary educational center for children. (Alfiana, 2013; Zahrok \& Suarmini, 2018). 
More specifically, parents' roles during the Covid-19 pandemic will be described below. Ensuring and Keeping Children to Implement a Clean and Healthy Life. Every parent wants their child to always be in good health, especially with the current conditions, namely during the COVID-19 pandemic, of course parents are becoming increasingly worried about it. One thing parents can do is remind their children to always apply a healthy and clean lifestyle to avoid various diseases and by teaching children to follow health protocols.

In line with what was expressed by Rompas et al., (2018) which stated that parents have a very important role in educating children, one of which is being and setting a good example for children, besides giving warnings and advice to children is also a important things that parents must do so that they always live clean to their children. ... take care of children's health, ensure that children are always healthy and maintain a healthy lifestyle, then ensure that children always follow government recommendations on how to carry out virus prevention SOPs... (excerpt from MN interview) ... go out with masks, sunbathe in the morning while being invited to play ... (excerpt from EI interview)

According to Graha (2007) the treatment of parents who always provide understanding and training to children about cleanliness and tidiness, will be able to make children always maintain personal hygiene. Not only reminding them to maintain a healthy lifestyle, the role of parents is also to maintain and ensure that children stay healthy, and ensure that children adopt a healthy lifestyle correctly. Oktaviani et al. (2017) stated that parents give love to their children not only in the form of education and trust, but it is also important to always control the development of their children.

As we know children can learn faster by imitating, so it is important that the example and habituation given by the teacher, especially parents. This is also in line with the opinion of Ihsani \& Santoso (2020) that the role of parents at home is very important in providing education to children to always maintain a clean environment, this education can be conveyed to children by giving examples to always wash their hands after activities outside, it is considered important to increase awareness about environmental hygiene. In addition, the role of parents is to ensure that children eat nutritious food, sleep regularly, wash their hands regularly, actively play, etc. (Dhiva, 2016).

Training children to always live clean and healthy is in line with one of the activities in the positive parenting program (Triple $\mathrm{P}$ ) which aims at developing individual capacity for self-regulation (Sanders, 2008). Individuals learn how to change their own behavior and become solutions to issues in the wider social environment connected to parenting and family life through self-regulation. (Karoly, in Sanders, 2008). Positive parenting can be used as a family parenting model so that it becomes a solution in maintaining and ensuring children live a healthy and clean life with self-regulation.

Guiding Children as They Complete Schoolwork To stop the Corona virus spread in schools, the Minister of Culture and Educationissued a policy for implementing education during the emergency period of the spread of the Corona virus (COVID-19) through a circular letter on March 24, 2020, regarding the policy of "learning from home." (BDR)". This means that parents temporarily take up the duty of teachers in assisting children with their homework at home. According to the findings of the field data analysis, the involvement of parents during the BDR time is primarily focused on assisting pupils in completing the duties assigned to them by the teacher at school.

This condition indicates that the BDR activities provided by the teacher are mainly on giving assignments as stated by Nahdi et al. (2020) that the activities provided by school institutions in the application of learning at home, one of which is the assignment or assignment. ...becoming a parent as well as a teacher in helping children to do their homework from school (UL interview excerpt) ...my child is already in kindergarten at Quran Kindergarten, which organizes online learning and many tasks that require parental guidance...(interview excerpt SS) 
This situation becomes interesting to study, what is the real meaning of learning from home? Does it have the same meaning as doing homework or homework? By giving such assignments, does it mean that the role of child learning mentoring can be said to be successful? The orientation of mentoring that focuses on doing school assignments shows that the orientation of Indonesian education still emphasizes aspects of academic achievement or cognitive development so that affective and psychomotor development can be said to be not a priority so they are not stimulated.

According to Mattewakkang, (2020) in the learning process at home (BDR) it is hoped that teachers and parents can realize education that does not only focus on academic or cognitive achievement, but can realize meaningful education, mutual understanding is needed from the government, schools, and the community. and these three elements must synergize with each other. Likewise, if we look at the goals of national education as controlled in the Law of the Republic of Indonesia Number 20 of 2003 article 3, namely "National education tries to help students reach their full potential as individuals who have faith in and fear God Almighty, have virtues, healthy, creative, knowledgeable, competent, self-sufficient, grow into democratic and responsible citizens."

Ensuring the success of the learning process implementation in a different atmosphere or at home in particular, curriculum design and learning in accordance to the conditions of COVID-19 pandemic, providing motivational encouragement and teachers' appreciation, parents and students, conducting online training and distance learning (PJJ), sending online reports on children's daily tasks to the education office, communicating not in one direction but multiple directions to sterilize educational units are an absolute must in this pandemic condition (Ansori, 2020).

The position of parents holds a critical part in their children's educational achievement so that they need to be provided with guides that are relevant for the children's present needs. The guide, for example, emphasizes clean and healthy living habits, communication, critical thinking, problem solving skills, and cooperation, media and technology information literacy, creativity and invention, and ICT, all of which are skills highly demanded in the 21 st-century. The process of parents mentoring their children during BDR will aid in the development of their sons and daughters. ... being an educator for children at home, such as assisting in learning, helping when there are difficulties for children ... (excerpt from MN interview) ...as an educator at home for their children, directly providing guidance and direction, replacing the role of teachers in schools to conduct teaching directly at home...(SF interview excerpt) ... self-study with parents in the form of tutorials from school via cell phone or online for our children to do at home, then guided and directed...(SF interview excerpt)

The interview excerpt above shows that basically mentoring efforts can be done in various ways, such as helping when students are facing difficulties, conducting teaching or even exploring new learning experiences via online tutorials and to optimize this, parents are required to increase their skills and knowledge, especially in ICT literacy that mainly focuses on affective, cognitive, and psychomotor to optimize all aspects of its development.

\section{Discussion}

Doing Activities Together While at Home, there are many types of activities taken out at home by parents and children, such as cleaning the house, cooking, playing, worshiping, etc. This is an excellent opportunity for parents and children to develop their ties with one another., in line with this UNICEF, (2020) reveals that there are numerous methods in which parents can assist in the parenting process during this pandemic situation, one of which is by making sure to spend quality time with children, for example to involve kindergarten age children in household chores such as cleaning the house or cooking, this can be used as an exciting game. 
At this point, parents take the role as developers of a variety of activities that can be done together with children. ... the activity of making meals with simple menus carried out with family members.... (excerpt from the hospital interview) ...must be a working partner in carrying out activities recommended by the government such as cleaning the house, beds, clothes, furniture and yard, which is carried out together with children . (excerpt from UL interview) ...we can take advantage of the situation at home even with limitations, with variations or more innovative activities, for example inviting them to play together at home, joking together, or making simple meals with family members. So that all family members will feel less bored at home for so long. (Excerpt from RS interview)

The quality of time that parents and children have during the pandemic can be used to build connection and ties among family members, Harmaini (2013) states that parental togetherness is very necessary because they understand their level of development and the things they need, togetherness with children begins since the child is not born until they are teenagers, according to the needs of each child.The hectic pace of modern life frequently results in limited time with youngsters. Even on holidays, when everyone in the family gathers, everyone is preoccupied with his or her own pursuits. Thus, parents' roles as activity developers can be carried out collaboratively by incorporating children in deciding the diversity of activities to be carried out so that children do not feel bored.

In accordance to the Ministry of and Culture and Education of the Republic of Indonesia (Ministry of Culture and Educationof the Republic of Indonesia, 2017), there are several activities that can be done together with children to create quality time, such as worshiping together, eating together, playing or exercising together, cooking together, cleaning the house together, and accompanying children in doing homework. schooling, watching television, accessing the internet, and using electronic devices. In line with that, Gloria (2020) states that parents must help each other, together with their children, then invite children to participate in homework, such as tidying up toys, making beds, watering plants, and so on. Apart from relieving boredom, conducting activities with children can help teach them new skills. Providing a Safe Environment for Children Together for three months and possibly more in a period of virtually 24 hours fosters the need to create a pleasant environment for all, both physically and mentally. psychological. Of course, parents should be the ones who know and understand their children the best, including how and when they should study (Prasetyono, 2008:32).

According to the Ministry of and Culture and Education(2017), the responsibility of parents at home is to establish habits, provide a secure, comfortable, and enjoyable environment, and positively nurture their children. Parents may provide comfort and a sense of security to their children through developing bonds with them, such as by offering affection through embraces, slings, hugs, and caresses. ...we are not too rigid with schedules, activities that are supposed to be done by family members, by children, both in learning hours and in other things. We can take advantage of the situation at home even though we have limitations... (excerpt from hospital interview) ...at times like this, parents must be able to give their best in dealing with or accompanying children.. such as being able to be both parents and teachers in helping children do their tasks. from school, then the next day we have to be friends who can balance the child's mood when the child wants to play and the next day maybe we have to be partners in doing activities...(UL interview excerpt) ...eliminating the boredom of the child, we can motivate him, we support it, let the child find something to follow...(SF interview excerpt)

Creating a comfortable environment is consistent with Raraswati's (in Hatimah, 2016) belief that the family is responsible to provide a pleasant learning environment at home, promote character, and accomplishment. According to the Ministry of and Culture and Education(2017), it is critical to do so for children's growth and development, as well as to build the bond between parents and children. Providing encouragement is also necessary so that children are confident to create and enjoy an environment that is not only safe for children, but also comfortable and fun. and can be done by doing activities together, such as playing, doing homework according to their abilities, chatting, and doing things the child likes. 
Establishing Intense Communication with Children One of the roles of parents is to establish good communication with children.

Communication between parents and children is crucial, according to Murtiningsih (2013), since it strengthens the bond between parents and children. Parents will be able to learn about their children's wants through communication, and they will be able to express their own desires, hopes, and support for their children. That manner, children will be more open to their parents, and parents will be more open to their children, resulting in a loving and comfortable family environment. ... sometimes we try to give funny jokes, stories about history, or stories about the difficulties faced by children...(excerpt from hospital interview) ...communicate so that children are disciplined with time in learning, the goal is to discipline children while studying at home (SF interview excerpt) Positive communication fosters positive parenting in the family, as seen by careful listening and attention on the discourse. Communication may be considered to be successful if the communicator avoids making mistakes when speaking, particularly when training youngsters (Sofyan, 2019). While playing, listening and discussing activities take place, establishing constructive parents and children communication.

One of the duties of the family, according to Raraswati (in Hatimah, 2016), is to provide a pleasant atmosphere for learning at home, as well as to foster warm and caring connections and communication with children. As a result, the youngster will feel at ease, safe, and enjoy being in a family setting. Playing with Children Parents said that during the pandemic, playing activities were the most frequently carried out, especially for parents who have early childhood and elementary school age children (Gloria, 2020; Ministry of Education and Culture, 2017; Ministry of Culture and Educationof the Republic of Indonesia). , 2017). This shows the basic nature of the child's world, namely playing. Children can learn a lot about something through playing activities, and playing is also a very important part of a child's growth and development (Prasetyono, 2008:5). In line with what is stated in the Ministry of Education and Culture, (2017) that the world of children is playing, through playing, leading to the development of children who are smart, cheerful and always healthy. Most of the children use their time to play, whether it's playing alone or with friends.

Field data shows that the play areas explored during the pandemic are indoors as well as outdoors. For families who still have access to the outdoors such as the yard or the back of the house, parents use them to play together such as playing swings, fishing for fish, looking for worms, hanging out with wild ducks, planting flowers, playing in water, etc., while playing activities at home mostly done by using existing toys such as planes, trains, toy cars, etc. as well as watching tv and playing gadgets are also play activities that are often done. ...children are also given the freedom to play...... play with gadgets. (Excerpt from SF interview) ...children usually play on swings, look for worms, talk to wild ducks, fish, plant plants, chase cats... if they are indoors, they usually play with cars, planes, trains, watch TV... but the interaction is limited only with family just...(SP interview quote) ...inviting children to play, joking and laughing, but still paying attention to the limits of our jokes so that children respect their parents...(ED interview quote) ...for example inviting them to play together in the house, joking together...(RS interview quote) ... giving children the freedom to play, obeying the children's play as they pleased, and also not restraining the children. Don't forget to also support children to learn while playing, and as long as they don't leave the house, because the current situation is vulnerable (SS interview excerpt)

Playing activities together will encourage children to behave positively in accordance with the needs and expectations of children, and it is hoped that the relationships that exist when playing together will consistently prevent problematic behavior as well as a way to build and maintain a positive family atmosphere (Bluth \& Wahler, 2003). 2011). Togetherness and intimacy in the family will build positive parenting, which contains a dimension of compassion, which is defined as the desire to represent one's emotions in alleviating suffering (Lazarus and Lazarus, 1994, in Duncan et al., 2009). Positive parenting is basically carried out to meet the basic needs of children such as love, security and a sense of comfort. 
Becoming a Children's Role Model Parents are the most mature members of the family, and they are the leaders of the family. Children in a family system will mimic and emulate their parents' actions.

According to Rakhmawati (2015), children will copy their parents' conduct because they witness it, whether it is positive or negative, things that children imitate, such as routines, parental interactions, behavior, or everyday activities carried out by parents. As a result, parents become the child's initial source of learning since youngsters have an innate need to emulate a profession, both from their parents and from others. (Taubah, 2016) ...giving an example to family members, that during the corona pandemic the first thing that must be taken care of is health, secondly, routine activities of an educational or work nature can be done from home...(excerpt from hospital interview) ...to get into the habit of washing hands and feet after playing outside, by washing together, so that they become an example for children...(SP interview excerpt) ... because the interaction is now limited, so AH and IZ rarely fight when playing together, we also get used to saying thank you... or sorry or punten...if given something or doing something... (SP interview excerpt) In parenting, parents play a role in guiding and educating their children so that they can carry out their social life.

In line with this, Jannah (2012) suggests that through parenting can shape moral development in children. To form good moral development, It is essential to have a good role model who is exhibited on a daily basis at home. Parents' position as role models will inspire children to act appropriately as anticipated and will help to prevent negative conduct in the future. Providing Family Members with Supervision, Parents will provide the function of supervision on the clean and healthy living behavior pattern (PHBS) and the execution of children's learning activities. The function of supervision demonstrates that in the family, parents are a subsystem connected to parental relationship with children, in which their duty is to protect, raise, and punish children (Pratiwi et al., 2018). In line with this, it is stated in Government Regulation Number 87 of 2013 (in Puspitawati, 2018: 135), that the family's function is to protect through establishing and creating a sense of security in the family in terms of both physical, economic, and psychosocial security, as well as comfort.

In this case, parents protect their family members in the form and act as supervisors for their children from things that make children insecure or uneasy. ...the role of parents in supervising the family members from the spread of COVID-19 by providing education to family members, especially to children,...(excerpt from hospital interview) ....in addition to being a supervisor in terms of the spread of the corona virus or its health side, it is also in this still directs and gives motivation or encouragement to continue to carry out and follow their learning activities... (excerpt from hospital interview) One strategy to protect family members is to play the position of supervisor. This function is related to the dimensions of knowledge and acceptance of non-judgment, and it entails paying particular attention to the numerous attributions and expectations that parents have about parenting relationships (Duncan et al., 2009).

Positive parenting interactions are perceived as positive when there is mutual understanding and acceptance between the child and the parent, resulting in a sense of security for the child. Supporting and Fulfilling Family Needs The role of parents as breadwinners is not only during the Covid-19 pandemic, but even in normal situations, parents have this role. This pandemic, on the other hand, drives families to work harder, both father and mother, to meet the family's fundamental necessities. Many families have lost their jobs, resulting in a loss of income and an inability to meet the family's financial needs. In reality, one of the family's functions is economic, in that the family becomes a supporter of meeting needs in order to achieve family welfare (PP No. 87 of 2014, in Puspitawati, 2018: 136). ...try and endeavor. The effort is to find money to meet the needs of the family, don't just stay at home, except for those who have a fixed salary, it's difficult for entrepreneurs... (ED interview quote) ...helping husbands in the economic field. Because of this virus, the average family is affected by the economy, so there needs to be additional effort...(LQ interview excerpt) Providing for the family's fundamental requirements is an effort to offer care and education. In this instance, the family has obligations and responsibilities, including meeting children's basic requirements, such as caring, educating, and protecting them (Law of the Republic of 
Indonesia Number 35 of 2014 regarding Amendments to Law Number 23 of 2002 about Child Protection, 2014). A prosperous or harmonious family is defined by the ability to meet a family's basic needs (Puspitawati, 2013).

Family dysfunction in meeting basic needs will have an impact on family harmony, especially in the current situation. Family efforts in meeting the needs are part of positive parenting, where relationships are built continuously between parents and children or between children which include consistently and unconditionally nurturing, teaching, leading, communicating, and providing for children's needs Seay and colleagues, 2014). Guiding and Motivating Children Learning from home (BDR) activities children carry out various problems as a result of the pandemic, including a lack of enthusiasm for studying and boredom. As mentioned in Nurkholis's research (2020) that the effect of the Covid-19 situation on students is boredom and boredom. In this instance, parents' responsibility is to guide and motivate their children so that they continue to be motivated about doing things at home. Essentially, children are motivated to pursue anything if they receive support from the individual's closest to them, such as their parents (Yulianti, 2014).

According to Sardiman (Harahap, 2018) suggests that motivation is a sequence of actions taken to produce a particular situation to stimulate the the desire to do and achieve something. As a way of parenting their children, parents take on these roles. As described by some parents below. ...children need more guidance from parents. So, as mothers, we have to be more patient with our children, because when children study with their parents, it's different if they are more obedient to the teacher. When the guidance and direction does not yell at the child, so that the child is motivated to learn... (excerpt from LQ interview) ...to direct and give motivation or encouragement to continue implementing and following learning at home in accordance with what is required by educational institutions... (excerpt from hospital interview)

...when the child gets bored, invite the child to cook or also help the child study at home...balance the child's mood when the child wants to play... (UL interview quote) ... so that I don't get bored at home, I usually take my child outside to play in the yard... (SP interview excerpt)

Parents must interpret the scenario that their child is in and respond appropriately. Responsiveness, including affection, support, and warmth (Lestari, 2012). In guiding and motivating children, Parents must focus on how to communicate with their children when guiding and motivating them. Communication is said to be effective when parents focus on how to communicate with their children when guiding and motivathem. Communication is said to be effective when parents and children enjoy, understand, and are open to one another (Jatmikowati, 2018). In addition, guiding and providing motivation requires emotional awareness which is the basis of parenting, because strong emotions have a strong influence in triggering automatic thought processes including behaviors that tend to be destructive (Duncan et al., 2009).

\section{Conclusion}

According to the discussion and analysis of data, it can be concluded that the findings suggest that in general, the role of parents emerging during the covid-19 pandemic is that of guidance, educator, caregiver, developer and Supervisors, and specifically indicate that the role of the parent is to care for the child. And ensure that children maintain a healthy and clean way of life, accompany children in school, do activities together at home, create a safe and comfortable environment, play together, maintain close ties and communication, be a role model, supervise the family, provide for and fulfill family necessities, guide and encourage children, uphold religion values, provide education, change and innovate in family activities. 


\section{Suggestion}

To maintain positive interactions in child care, parents must engage in a variety of activities. This is not only intended for children, but also for their parents. Parents must have fun experiences or activities in order to keep children learning fun. One of the factors that may increase a parent's success in positive parenting is affection's function in meeting the needs and providing comfort to the right child.

\section{References}

Alwasilah, A. C. (2002). Pokoknya kualitatif : dasar-dasar merancang dan melakukan penelitian kualitatif. Pustaka Jaya.

Alfiana, E. (2013). Pola Asuh Orang Tua Terhadap Anak Dalam Keluarga Pada Bidang Pendidikan Di Dusun Pandanan Desa Pandanan Kecamatan Wonosari Kabupaten Klaten [Universitas Negeri Yogyakarta]. In Skripsi. https://doi.org/10.1016/j.bbapap.2013.06.007

Ansori. (2020). Peran Kepala Sekolah di Saat Pandemi Covid-19. Www.Pintar.Tanotofoundation.Org. https://www.pintar.tanotofoundation.org/peran-kepala-sekolah-di-saat-pandemicovid-19/

Arsendy, S., Sukoco, G. A., \& Purba, R. E. (2020). Riset dampak COVID-19: potret gap akses online 'Belajar dari Rumah' dari 4 provinsi. Theconversation.Com. https://theconversation.com/risetdampak-covid-19-potret-gap-akses-online-belajardari-rumah-dari-4-provinsi-136534

Bluth, K., \& Wahler, R. G. (2011). Does Effort Matter in Mindful Parenting? Mindfulness, 2(3), 175178. https://doi.org/10.1007/s12671-011-0056-3

Candra, A. N., Sofia2, A., \& Anggraini, G. F. (2013). Gaya Pengasuhan Orang Tua pada Anak usia Dini Ariya. Journal of Chemical Information and Modeling, 53(9), 1689-1699. https://doi.org/10.1017/CBO9781107415324.004 Covid19.go.id. (2020). Data Sebaran. Covid19.Go.Id. https://covid19.go.id/

Dhiva, A. A. (2016). 6 Panduan Penting Dalam Menjaga Kesehatan Anak. Parentingclub.Co.Id. https://www.parentingclub.co.id/smart-stories/6-panduan-penting-dalammenjaga-kesehatan-anak

Duncan, L. G., Coatsworth, J. D., \& Greenberg, M. T. (2009). A Model of Mindful Parenting: Implications for Parent-Child Relationships and Prevention Research. Clinical Child and Family Psychology Review, 12(3), 255-270. https://doi.org/10.1007/s10567-009-0046-3

Gloria. (2020). Sehat Mental Selama di Rumah dengan Aktivitas Positif Bersama Keluarga. Ugm.Ac.Id. https://ugm.ac.id/id/newsPdf/19175-sehat-mental-selama-di-rumahdengan-aktivitas-positif-bersamakeluarga

Graha, C. (2007). Kebersihan Anak di Tangan Orang Tua Paunduan Bagi Orang Tua Untuk Memahami Perannya dalam Membantu Keberhasilan. PT Elex Media.

Harahap, F. I. N. (2018). Pengaruh Hasil Program Parenting Dan Pola Asuh Orang Tua Terhadap Peningkatan Motivasi Belajar Anak Usia Dini. Al-Muaddib : Jurnal Ilmu-Ilmu Sosial \& Keislaman, 3(1), 1-15. https://doi.org/10.31604/muaddib.v1i1.367 
Hardiyana, A. (2016). Optimalisasi Pemanfaatan Teknologi Informasi Dan Komunikasi Dalam Pembelajaran Paud. Awlady: Jurnal Pendidikan Anak, 2(1), 1-12. https://doi.org/10.24235/awlady.v2i1.762.g603

Harmaini. (2013). Keberadaan Orang Tua Bersama Anak. Jurnal Psikologi UIN Sultan Syarif Kasim Riau. Hatimah, I. (2016). Keterlibatan Keluarga Dalam Kegiatan Di Sekolah Dalam Perspektif Kemitraan. Pedagogia, 14(2), 290-297. https://doi.org/10.17509/pedagogia.v14i2.3878

Heriyanto, H. (2018). Thematic Analysis sebagai Metode Menganalisa Data untuk Penelitian Kualitatif. Anuva. https://doi.org/10.14710/anuva.2.3.317-324

Hyoscyamina, D. E. (2011). Peran Keluarga Dalam Membangun Karakter Anak. Jurnal Psikologi, 10(2), 144-152. https://doi.org/https://doi.org/10.14710/jpu.10.2.144-152

Ihsani, I., \& Santoso, M. B. (2020). Edukasi Sanitasi Lingkungan Dengan Menerapkan Perilaku Hidup Bersih Dan Sehat (Phbs) Pada Kelompok Usia Prasekolah Di Taman Asuh Anak Muslim Ar-Ridho Tasikmalaya. Prosiding Penelitian Dan Pengabdian Kepada Masyarakat, 6(3), 289. https://doi.org/10.24198/jppm.v6i3.22987

Jannah, H. (2012). Perilaku Moral Pada Anak Usia Di Kecamatan Ampek. Bentuk Pola Asuh Orang Tua Dalam Menanamkan Perilaku Moral Pada Anak Usia Di Kecamatan Ampek Angkek, 1, 257-258.

Jatmikowati, T. E. (2018). Efektifitas Komunikasi Orang Tua Terhadap Kepribadian Intrapersonal Anak. Pedagogi: Jurnal Anak Usia Dini Dan Pendidikan Anak Usia Dini, 4(2), 1-15. https://doi.org/http://dx.doi.org/10.30651/pedagogi.v4i2.1936

Kementerian Pendidikan dan Kebudayaan. (2017). Menjadi Orang Tua Hebat Untuk Keluarga dengan Anak Usia Dini. In My Hero (Vol. 98, Issue 25). Kementerian Pendidikan dan Kebudayaan. http://118.98.227.114/glnsite/wpcontent/uploads/2017/09/Juknis_PAUD.pdf

\section{Copyrights}

Copyright for this article is retained by the author(s), with first publication rights granted to the journal.

This is an open-access article distributed under the terms and conditions of the Creative Commons Attribution license (http://creativecommons.org/licenses/by/4.0/). 